\title{
SISTEM PENGEMBANGAN DAN REGULASI WAKAF
}

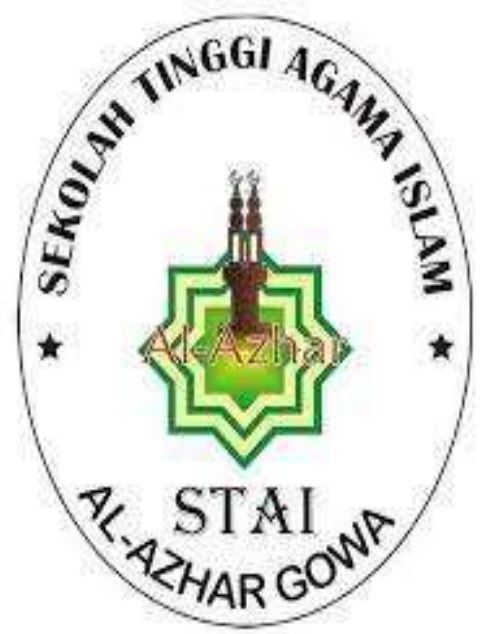

Makalah Ini Diajukan Untuk Memenuhi Tugas Mata Kuliah Fiqh Zakat dan Wakaf

Oleh :

Musfirah HR.

Nurul Fani Fajrianti Rusliah

Dosen Pengampu :

Samsul Arifai, S.A.B., M.A.

Prodi Ekonomi Syariah

Sekolah Tinggi Agama Islam (STAI) Al-Azhar Gowa 


\section{KATA PENGANTAR}

Puji syukur kehadirat Allah subhanahu wata'ala atas segala rahmat-Nya sehingga makalah ini dapat tersusun sampai dengan selesai. Tidak lupa kami ucapkan terima kasih terhadap pihak yang telah berkontribusi dengan memberikan sumbangan baik pikiran maupun materinya.

Penulis berharap semoga makalah ini dapat menambah pengetahuan dan pengalaman bagi pembaca. Bahkan kami berharap lebih jauh lagi agar makalah ini bisa pembaca sekalian praktekkan dalam kehidupan sehari-hari.

Bagi kami sebagai penyusun merasa bahwa masih banyak kekurangan dalam penyusunan dalam makalah ini karena keterbatasan pengetahuan dan pengalaman kami. Untuk itu kami sangat menhgarapkan kritik dan saran yang membangun dari pembaca demi kesempurnaan makalah ini.

Makassar, 01 Desember 2021 


\section{DAFTAR ISI}

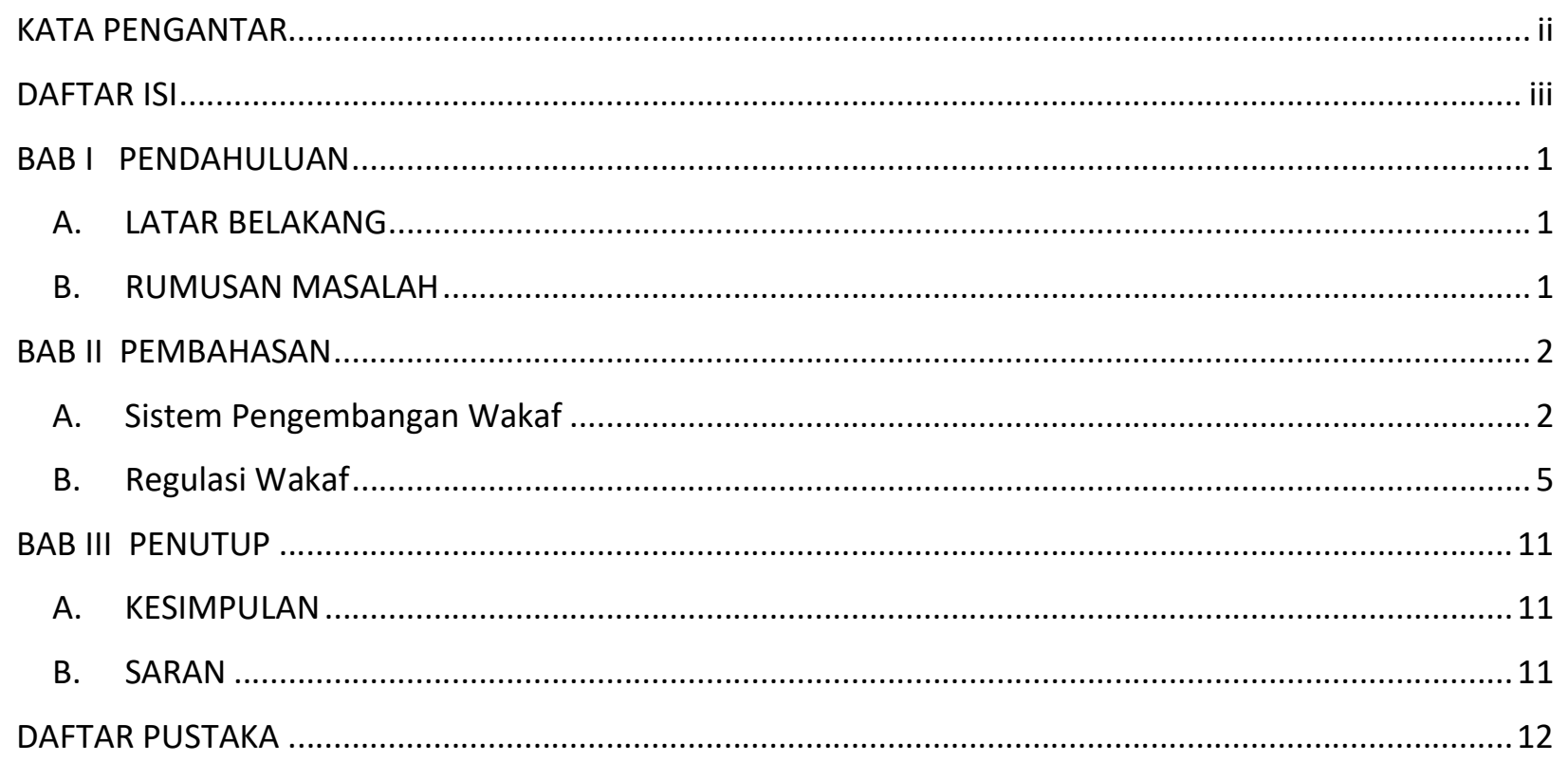




\section{BAB I \\ PENDAHULUAN}

\section{A. LATAR BELAKANG}

Wakaf merupakan ibadah yang bercorak sosial ekonomi yang cukup penting. Menurut sejarah Islam klasik, wakaf telah memainkan peran yang sangat signifikan dalam meningkatkan kesejahteraan kaum muslimin, baik di bidang pendidikan, pelayanan kesehatan, pelayanan sosial dankepentingan umum, kegiatan keagamaan, pengembangan ilmupengetahuan serta peradaban Islam secara umum.

Kemudian pelaksanaan wakaf diatur oleh Undang-undang Nomor 5 Tahun 1960 tentang: Peraturan Dasar Pokok Agraria dan Peraturan Pemerintah Nomor 28 Tahun 1977 tentang: Perwakafan Tanah Milik. Peraturan itu hanya mengatur dari sisi administratif dan kepemilikan tetapi belum menyentuh soal pengelolaannya. Sesuai perkembangan ilmu ekonomi dan ilmu hukum di Indonesia, wakaf yang merupakan produk ijtihad, yang akhirakhir ini telah mengalami perubahan yang sangat signifikan. Pada akhir tahun 2004 Indonesia telah mengesahkan undang undang wakaf yang merupakan titik awal paradigma baru tentang pamahaman wakaf di Indonesia.

Diantara beberapa perkembangan yang terdapat dalam Undang Undang Nomor 41 Tahun 2004 tentang wakaf adalah tentang harta wakaf, institusionalisasi wakaf dan manajemen pengembangan wakaf. ${ }^{1}$

\section{B. RUMUSAN MASALAH}

1. Bagaimanakah sistem pemngembangan wakaf?

2. Bagaimanakah regulasi wakaf?

\footnotetext{
${ }^{1}$ Veithzal Rizal ainal, 'PENGELOLAAN DAN PENGEMBANGAN WAKAF PRODUKTIF Oleh : Veithzal Rivai Zainal
} Anggota Dewan Pertimbangan Badan Wakaf Indonesia (BWI)', Ziswaf, 9 (2016), 1-16. 


\section{BAB II \\ PEMBAHASAN}

\section{A. Sistem Pengembangan Wakaf}

Pada masa ini, wakaf awalnya hanyalah keinginan seseorang yang berbuat baik dengan kekayaan yang dimilikinya dan dikelola secara individu tanpa ada aturan yang pasti. Namun setelah kaum Muslimin merasakan betapa besarnya manfaat lembaga wakaf, maka timbullah keinginan untuk mengatur perwakafan dengan baik. Kemudian dibentuk lembaga yang mengatur wakaf untuk mengelola, memelihara dan menggunakan harta wakaf, baik secara kelompok maupun secara umum.

Indonesia sebagai negara mayoritas muslim tentu memiliki potensi wakaf uang yang sangat besar. Menurut Nasution (2012), potensi wakaf uang di Indonesia dengan jumlah umat muslim dermawan diperkirakan sebanyak 20 juta umat dan mewakafkan hartanya dalam bentuk wakaf uang dengan nominal Rp 1 juta per tahun, maka potensi wakaf yang terkumpul bisa mencapai Rp 20 Triliun. Namun, di samping potensi yang besar, tidak sedikit tantangan dan ancaman yang dihadapi dalam kerangka pengembangan instrumen keuangan sosial Islam ini. Salah satu diantaranya misal, belum detailnya data terkait wakaf secara umum demikian juga terkait wakaf tunai.

Sebagian ulama madzhab Asy-Syafi'i. "Abu Tsaur meriwayatkan dari Iman al-Syafi'i tentang kebolehan wakaf dinar dan dirham (uang)".Mas'udi (2016) melakukan analisis terhadap pengembangan wakaf tunai (Waqf al-Nuqud) di Indonesia. Penelitian menunjukan bahwa upaya pengembangan wakaf uang di Indonesia relatif masih baru jika dibandingkan dengan negara lain. Untuk itu diperlukan sinergi antara lembaga nazhir wakaf dengan lembaga amil zakat agar aktivitas wakaf uang lebih cepat berkembang, khususnya pada masa-masa awal pertumbuhannya. Diperlukan peran yang lebih besar dari Lembaga Keuangan Syariah Penerima Wakaf Uang agar sinergi antara nazhir wakaf dengan LKS PWU profesional lebih maksimal.Haura Arie et al. (2016) melakukan analisis pengelolaan wakaf uang pada Koperasi Jasa Keuangan Syariah. 
Sebagai instrumen yang baru dalam konstelasi ekonomi Indonesia, wakaf tunai mendapat respon yang positif dari beberapa pengamat ekonomi. Wakaf tunai dinilai menjadi jalan alternative untuk melepas ketergantungan bangsa ini dari lembaga-lembaga kreditor sekaligus menstimulasi pertumbuhan ekonomi Indonesia. Optimalisasi wakaf bisa lebih luas dari zakat karena tak ada kualifikasi mustahiq (8 ashnaf penerima wakaf). Dana wakaf dapat digunakan untuk segala kegiatan yang baik termasuk menunjang sektor usaha bagi kaum dhuafa. Sebagai Negara yang mayoritas penduduknya muslim, eksistensi insrumen syariah ini akan sangat acceptable, sehingga wakaf tunai diperkirakan akan dapat memberikan kontribusi besar bagi percepatan pertumbuhan ekonomi Indonesia dan mampu menciptakan efek multiplier bagi kaum dhuafa. ${ }^{2}$

Distribusi hasil wakaf tunai memang bisa diarahkan pada program penyantunan (charity) kaun dhua ${ }^{e e} f a$, akan tetapi sebaiknya hal itu baru dilakukan apabila keadaannya benar-benar mendesak. Sebab dengan program itu, modal akan habis dalam sekali pakai. Sebisa mungkin keuntungan investasi wakaf tunai dipakai untuk program pemberdayaan (empowerment) rakyat miskin sehingga modal dapat digunakan secara berkenjutan, bahkan apabila memungkinkan modal tersebut bisa diputar kepada orang lain yang juga membutuhkan, baik dalam rangka memperkuat kapasitas distributif ataupun sebagai modal awal untuk memualai sebuah usaha (kapasitas produktif). ${ }^{3}$

Bahkan MUI juga telah mengeluarkan fatwa tentang wakaf tunai sebagai berikut :

1) Wakaf uang (cash wakaf/ waqf al-Nuqut) adalah wakaf yang dilakukan oleh sekelompok atau seseorang maupun badan hukum yang berbentuk wakaf tunai.

2) Termasuk dalam pengertian uang adalah surat - surat berharga.

3) Wakaf yang hukumnya jawaz (boleh).

4) Wakaf yang hanya boleh disalurkan dan digunakan untuk hal - hal yang dibolehkan secara syar ' $\mathrm{i}$.

5) Nilai pokok wakaf yang harus dijamin kelestariannya, tidak boleh dijual, dihibahkan atau diwariskan.

\footnotetext{
2 M. Anwar Nawawi, 'Pengembangan Wakaf Uang Tunai Sebagai Sistem Pemeberdayaan Umat Dalam Pandangan Ulama Konvensional Dan Kontemporer M.', Journal of Chemical Information and Modeling, 53.9 (2013), 1689-99. ${ }^{3}$ Marpuji Ali, 'Wakaf Dan Pemberdayaan Umat', Makalah Yang Disampaikan Dalam Seminar on Islamic Economics as a Solution, 2015.
} 
Selain fatwa MUI diatas, pemerintah melalui DPR juga telah mengesahkan undangundang No. 41 tahun 2004 tentang wakaf, yang didalamnya juga mengatur bolehnya wakaf berupa uang.

Terdapat beberapa kendala yang menjadi hambatan implementasi wakaf tunai sesuai ketentuan UU No. 41 Tahun 2004, di antaranya;

1) Badan Wakaf Indonesia (BWI) tidak memiliki tenaga operasional di bidang wakaf uang yang cukup memadai;

2) Prinsip yang digunakan dalam pelaksanaan wakaf uang terlalu kaku, yaitu bank adalah murni sebagai bank. Sehingga, wakif yang melakukan wakaf tunai diberlakukan sama dengan nasabah lainnya;

3) Sesuai UU No. 41 Tahun 2004 Pasal 59 disebutkan; "Dalam rangka pelaksanaan tugas Badan Wakaf Indonesia, Pemerintah wajib membantu biaya operasional. Namun, dalam kenyataannya dana yang diberikan oleh Kementerian Agama kepada BWI terlalu kecil. ${ }^{4}$

Benda wakaf terbagi menjadi dua, yaitu :

1) Harta benda tidak bergerak. Benda tidak bergerak ini seperti tanah, bangunan, pohon untuk diambil buahnya, sumur untuk diambil airnya. Benda-benda macam inilah yang sangat dianjurkan, karena mempunyai nilai jariyah lebih lama. Ini sejalan dengan praktek wakaf yang dilakukan oleh sahabat Umar bin Khattab atas tanah Khaibar atas perintah Rasulullah SAW.

2) Harta benda bergerak Harta benda yang bergerak terdiri dari ; Wakaf hewan, Wakaf hewan sendiri ini tergolong dalam wakaf benda untuk diambil manfaatnya, seperti kuda yang digunakan mujahidin untuk berjihad. Atau bisa juga wakaf hewan sapi yang diberikan kepada pelajar untuk diminum air susunya. ${ }^{5}$

\footnotetext{
${ }^{4}$ Abdurrahman Kasdi, 'Peran Pemerintah Dalam Regulasi Perundang-Undangan Wakaf', ZISWAF : Jurnal Zakat Dan Wakaf, 4(1), 87. Https://Doi.Org/10.21043/Ziswaf.V4i1.3033, 2.2 (2015), 362-79.

${ }^{5}$ Tina Istiana, 'PERBANDINGAN REGULASI TANAH WAKAF ANTARA INDONESIA DAN MALAYSIA', 2021, 1-17.
} 
Manfaat wakaf uang tunai :

1) Seseorang yang memiliki dana terbatas sudah bisa mulai memberikan dana wakafnya tanpa harus menunggu menjadi tuan tanah terlebih dahulu.

2) Melalui wakaf uang, asset-asset berupa tanahtanah kosong bisa mulai dimanfaatkan dengan sarana yang lebih produktif untuk kepentingan umat.

3) Dana wakaf tunai juga bisa membantu sebahagian lembaga-lembaga pendidikan islam.

\section{Sertifikat wakaf tunai}

Sertifikat wakaf tunai adalah salah satu instrument yang sangat potensial dan menjanjikan, yang dapat dipakai untuk menghimpun dana umat dalam jumlah besar. Sertifikat wakaf tunai merupakan semacam dana abadi yang diberikan oleh individu maupun lembaga muslim yang mana keuntungan dari dana tersebut akan digunakan untuk kesejahteraan masyarakat. Sertifikat wakaf tunai ini dapat dikelola oleh suatu badan investasi sosial tersendiri atau dapat juga menjadi salah satu produk dari institusi perbankkan syariah. Tujuan dari sertifikat wakaf tunai adalah sebagai berikut:

1) Membantu dalam pemberdayaan tabungan sosial.

2) Melengkapi jasa perbankkan sebagai fasilitator yang menciptakan wakaf tunai serta membantu pengelolaan wakaf.

\section{B. Regulasi Wakaf}

Kebijakan tentang regulasi wakaf di Indonesia dimulai sejak pemerintah kolonial Belanda, di mana antara tahun 1903 sampai 1935, Belanda mengeluarkan empat surat edaran Sekretaris (Circulaires van de Gouvernements Secretaris) kepada pemimpin Indonesia. Semua surat edaran tersebut meminta bupati untuk menangani pendaftaran bangunan keagamaan Muslim menyangkut asal-usulnya, statusnya sebagai tempat peribadatan, dan apakah ia berasal dari wakaf atau bukan. Pengaruh surat edaran ini setidaknya ada dua hal: Pertama, pemerintah telah mengendalikan kegiatan wakaf melalui wajib daftar, maupun keharusan meminta izin para bupati untuk mendermakan kekayaan sebagai wakaf. Kedua, bupati diberi kewenangan untuk menangani kasus-kasus yang berkaitan dengan sengketa wakaf. Dalam kurun waktu tersebut, 
ketentuan-ketentuan hukum wakaf secara umum hanya mengatur wewenang, prosedur perizinan dan pendaftaran tanah wakaf serta hal-hal administratif lainnya.

Setelah Indonesia merdeka, regulasi wakaf semakin berkembang positif, dengan keluarnya Peraturan Departemen Agama pada 22 Desember 1953 tentang prosedur pemberian tanah wakaf, yang kemudian diatur kembali oleh Surat Edaran Departemen Agama No. 5/D/1956. Kemudian, diterbitkannya Undang-undang Nomor 5 Tahun 1960 tentang Peraturan Dasar Pokok-Pokok Agraria.

Dalam Undang-undang ini, aset wakaf mendapatkan dasar hukum yang tetap, di mana negara secara resmi menyatakan perlindungan terhadap harta wakaf. Dalam Pasal 49 ayat 3 disebutkan bahwa perwakafan tanah milik dilindungi dan diatur menurut peraturan pemerintah. Perlindungan atas aset wakaf juga dipertegas kembali dalam Peraturan Pemerintah No. 10 Tahun 1961 tentang Pendaftaran Tanah. Peraturan ini meningkatkan penertiban sertifikasi tanah atas tanah wakaf yang telah diikrarkan.

Setelah mendapatkan jaminan perlindungan dari pemerintah, eksistensi wakaf semakin mendapatkan tempat dengan terbitnya Peraturan Pemerintah No. 28 Tahun 1977 tentang Perwakafan Tanah Milik, yang memuat unsur-unsur substansi dan teknis perwakafan. Terbitnya Peraturan Pemerintah No. 28 Tahun 1977 ini menciptakan pembaruan yang sangat penting dalam pengelolaan harta wakaf. Peraturan ini memberikan legalitas bagi bolehnya pertukaran harta wakaf setelah mendapatkan izin dari Menteri Agama. Secara subsansial peraturan tersebut juga membolehkan pertukaran harta wakaf agar dapat diberdayakan secara optimal.

Pembaruan lain yang terjadi setelah terbitnya peraturan ini juga mencakup aspek teknis dalam perwakafan. Sejak peraturan ini, beberapa pengelola wakaf mulai bersikap selektif terhadap harta wakaf yang diserahkan kepada mereka dengan memperhatikan asas manfaat dari wakaf yang akan diserahkan. Aturan lain yang membawa pembaruan dalam pengelolaan wakaf adalah Instruksi Presiden No. 1 Tahun 1991 tentang Kompilasi Hukum Islam (KHI). Pembaruan dalam KHI ini pada dasarnya merupakan elaborasi dari prinsip pembaruan yang terdapat pada PP No. 28 Tahun 1977. Baik Inpres No. 1 Tahun 1991 maupun PP No. 28 Tahun 1977 diarahkan untuk unifikasi Mazhab dan hukum Islam di Indonesia. Beberapa perluasan aturan perwakafan dalam KHI antara lain berkaitan dengan objek wakaf, nazir dan sebagainya. 
Terkait dengan objek wakaf misalnya, dalam KHI disebutkan bahwa objek wakaf telah mencakup harta benda yang bergerak, sedangkan dalam PP No. 28 Tahun 1977 ketentuan seperti itu belum ada. Demikian halnya dengan nazir, dalam KHI jumlah nazir perseorangan tidak lagi dibatasi hanya sebanyak tiga orang, melainkan disesuaikan dengan kebutuhan manajemen wakaf.

Dalam Kompilasi Hukum Islam (KHI) disebutkan bahwa wakaf adalah: perbuatan hukum seseorang, kelompok orang, atau badan hukum dengan memisahkan sebagian harta benda miliknya dan melembagakannya untuk selama-lamanya guna kepentingan ibadah atau keperluan umum lainnya sesuai dengan ajaran Islam.

Definisi dalam KHI ini lebih luas dibandingkan definisi dalam PP Nomor 28 Tahun 1977. Hal ini karena pertama, dalam PP Nomor 28 Tahun 1977 pihak wakif hanya dua, yaitu perorangan dan badan hukum, sedangkan dalam KHI, pihak wakif bisa tiga, yaitu perorangan, kelompok orang, dan badan hukum. Kedua, dalam PP Nomor 28 Tahun 1977 ditetapkan bahwa wakaf yang diaturnya hanya tanah milik, karena PP ini diberlakukan atas dasar amanat Undang-undang Nomor 5 Tahun 1960 tentang Ketentuan Pokok Agraria. Dalam pasal 49 ayat 3 ditetapkan bahwa perwakafan tanah milik dilindungi dan diatur oleh peraturan pemerintah.

Fenomena di atas menunjukkan bahwa sejak masa kolonial, aturan wakaf telah ada terkait dengan administrasi dan pencatatan wakaf. Aturan Perundang-undangan wakaf tersebut terus berkembang sejalan dengan dinamika perkembangan dan pengelolaan wakaf di masyarakat. Dari sisi jumlah dan aset, harta wakaf terus meningkat. Namun, peningkatan tersebut tidak disertai upaya peningkatan mutu pengelolaan wakaf, terutama peningkatan mutu SDM maupun manajemennya. Oleh karena itu tidak heran jika wakaf produktif pada masa itu perkembangannya sangat lambat.

Saat ini telah lahir Undang-undang No. 41 tahun 2004 tentang wakaf dengan tujuan pokok untuk mendorong kemajuan pengelolaan wakaf di Indonesia. Dengan Undang-undang ini, sektor wakaf diharapkan mampu berfungsi sedemikian rupa, sehingga mendukung kesejahteraan sosial-ekonomi umat Islam. Apalagi para ulama dan pemerhati masalah-masalah wakaf dari berbagai ormas Islam, baik Nahdlatul Ulama (NU), Muhammadiyah, maupun ormas-ormas Islam lainnya mendukung proses legislasi wakaf ini dengan sungguh-sungguh. Konteks kelahiran dan motif terpenting regulasi wakaf tersebut adalah untuk peningkatan 
kesejahteraan ekonomi dan penguatan masyarakat sipil dengan memanfaatkan sumbersumber alternatif yang potensial dalam wakaf.

Dalam Undang-undang Nomor 41 Tahun 2004 tentang Wakaf, ditetapkan bahwa wakaf adalah: perbuatan hukum wakif untuk memisahkan atau menyerahkan sebagian harta benda miliknya untuk dimanfaatkan selamanya atau jangka waktu tertentu sesuai dengan ketentuannya guna keperluan ibadah atau kesejahteraan umum menurut syari'ah. Terhadap kelahiran Undang-undang ini, sebagian besar nazir memandang positif bahwa Undang-undang ini dapat memberikan kepastian hukum dan memperkuat lembaga wakaf.

Di samping itu, Undang-undang ini juga bisa mendorong masyarakat untuk berwakaf. Selain memiliki persepsi positif dengan hadirnya Undang-undang wakaf tersebut, sebagian besar juga mendukung keberadaan Badan Wakaf Indonesia (BWI) yang telah eksis di masyarakat. Badan ini diharapkan mampu menjamin terciptanya kemajuan pengelolaan wakaf untuk kegiatan produktif di satu sisi dan peningkatan fungsi pelayanan sosial keagamaan di sisi lain. Pentingnya regulasi Perundang-undangan wakaf ini bisa kita analisis dari beberapa pasal dalam Undang-undang No. 41 tahun 2004. Dalam pasal 4 dan pasal 5 dinyatakan bahwa wakaf bertujuan memanfaatkan harta benda wakaf sesuai dengan fungsinya; wakaf berfungsi mewujudkan potensi dan manfaat ekonomis harta benda wakaf untuk kepentingan ibadah dan untuk memajukan kesejahteraan umum. Juga dalam pasal 12 mengenai peruntukan harta benda wakaf disebutkan bahwa dalam rangka mencapai tujuan dan fungsi wakaf, harta benda wakaf hanya dapat diperuntukkan bagi:

1) Sarana dan kegiatan ibadah;

2) Sarana dan kegiatan pendidikan serta kesehatan;

3) Bantuan kepada fakir miskin, anak terlantar, yatim piatu, beasiswa;

4) Kemajuan dan peningkatan ekonomi umat;

5) Kemajuan kesejahteraan umum lainnya yang tidak bertentangandengan syariat dan peraturan Undang-undang yang berlaku. ${ }^{6}$

Regulasi wakaf pada era Orde Baru juga diatur dalam UU No. 7 Tahun 1989 tentang Peradilan Agama, dalam Bab III tentang Kekuasaan Pengadilan Pasal 49 (1)

${ }^{6}$ Kasdi. 
menyebutkan bahwa Pengadilan Agama bertugas dan berwenang memeriksa, memutus dan menyelesaikan perkara perkara di tingkat pertama antara orang-orang yang beragama Islam di bidang perkawinan, kewarisan, wasiat, dan hibah, yang dilakukan berdasarkan hukum Islam, wakaf dan sedekah.

Regulasi selanjutnya yang mengatur tentang wakaf pada masa Orde Baru adalah Kompilasi Hukum Islam berdasarkan Inpres No.1 Tahun 1991. Pada Bab III KHI itu mengatur hukum perwakafan, yang terdiri dari lima bab dan limabelas pasal.

Dalam tinjauan politik hukum, PP No. 28 Tahun 1977 tentang Perwakafan Tanah Milik dilatarbelakangi atas dua hal;

1) Tertib administrasi perwakafan;

2) Proteksi terhadap gerakan komunisme. Hal ini tercermin dari Penjelasan atas Peraturan Pemerintah Nomor 28 Tahun 1977 tentang Perwakafan Tanah Milik yang dikeluarkan oleh Menteri Dalam Negeri, Amirmachmud, pada tanggal 26 November 1977.

Pada penjelasan umum disebutkan; di lain pihak banyak terdapat persengketaanpersengketaan tanah disebabkan tidak jelas status tanahnya, sehingga apabila tidak segera diadakan pengaturan, maka tidak saja akan mengurangi kesadaran beragama dari mereka yang menganut ajaran Islam, bahkan lebih jauh akan menghambat usaha-usaha pemerintah untuk menggalakkan semangat dan bimbingan "kewajiban ke arah beragama" (menjauhi faham dan gerakan komunisme), sebagaimana terkandung dalam ajaran Pancasila digariskan dalam Ketetapan Majelis Permusyawaratan Rakyat Nomor IV/MPR/1973.

Upaya politis pemerintah untuk melakukan tertib administrasi dalam rangka menjaga stabilitas nasional, juga secara eksplisit disebutkan di dalam konsideran PP No. 28 Tahun 1977. Ada tiga hal yang secara administratif menjadi alasan lahirnya PP No. 28 Tahun 1977.

1) Pada waktu yang lampau, pengaturan tentang perwakafan tanah selain dari belum memenuhi kebutuhan, juga belum diatur secara tuntas dalam suatu peraturan perundang-undangan, sehingga memudahkan terjadinya penyimpangan dari hakikat dan tujuan wakaf itu sendiri. Ini disebabkan karena beraneka ragamnya bentuk wakaf (wakaf keluarga dan wakaf umum) dan tidak adanya keharusan mendaftarkan benda-benda yang diwakafkan itu. Akibatnya, 
banyak benda-benda yang diwakafkan tidak diketahui lagi keadaannya, bahkan ada di antaranya yang telah menjadi milik ahli waris pengurus (nadzir) wakaf bersangkutan. Hal ini akan menimbulkan.

2) Keresahan di kalangan umat Islam yang menjurus kepada perasaan antipati terhadap wakaf.

3) Dalam masyarakat banyak terjadi persengketaan mengenai tanah wakaf karena tidak jelas status tanah wakaf yang bersangkutan.

Pemerintahan Orde Baru menetapkan ekonomi sebagai sentral di bidang pembangunan, maka stabilitas nasional menjadi syarat mutlak bagi terwujudnya tujuan itu. Sebab, tanpa stabilitas nasional yang mantap terutama di bidang politik, labilitaslabilitas dalam masyarakat dan kegoncangan-kegoncangan ekonomi dapat menghambat pembangunan secara keseluruhan. Dalam kondisi seperti itu, kepastian dan ketertiban melalui hukum sangat dibutuhkan.

Sebagai tindak lanjut dari upaya mewujudkan tertib hukum di bidang wakaf guna menjaga stabilitas nasional, maka pemerintah mengeluarkan beberapa peraturan yang mendukung PP No. 28 Tahun 1977 tentang Perwakafan Tanah Milik.

Untuk menciptakan tertib hukum dan administrasi, perwakafan tanah milik yang diatur di dalam PP No. 28 Tahun 1977 ditangani oleh dua departemen secara terpadu yaitu Departemen Agama dan Departemen Dalam Negeri, sesuai kewenangan masingmasing. Peraturan dua Departemen Implementasi terpadu antar dua departemen itu sesuai dengan isi UU No. 28 Tahun 1977, yang mengatur pembagian tugas perwakafan tanah milik; Departemen Agama bertugas pada ikrar wakaf dan pembuatan akta ikrar wakaf serta menerima laporan setelah mendapatkan pencatatan dan sertifikat, sedangkan Departemen Dalam Negeri bertugas mencatat dan menerbitkan sertifikat wakaf, sebagaimana dijelaskan pada Pasal 9 dan 10 PP No. 28 Tahun 1977. ${ }^{7}$

\footnotetext{
${ }^{7}$ Supriyadi Supriyadi and Sholihul Hadi, 'Regulasi Wakaf Di Indonesia Dari Masa Orde Lama Sampai Era Reformasi Dalam Tinjauan Politik Hukum', ZISWAF : Jurnal Zakat Dan Wakaf, 6.2 (2019), 204 <https://doi.org/10.21043/ziswaf.v6i2.6418>.
} 


\section{BAB III \\ PENUTUP}

\section{A. KESIMPULAN}

1. Indonesia sebagai negara mayoritas muslim tentu memiliki potensi wakaf uang yang sangat besar. Menurut Nasution (2012), potensi wakaf uang di Indonesia dengan jumlah umat muslim dermawan diperkirakan sebanyak 20 juta umat dan mewakafkan hartanya dalam bentuk wakaf uang dengan nominal Rp 1 juta per tahun, maka potensi wakaf yang terkumpul bisa mencapai Rp 20 Triliun. Namun, di samping potensi yang besar, tidak sedikit tantangan dan ancaman yang dihadapi dalam kerangka pengembangan instrumen keuangan sosial Islam ini. Salah satu diantaranya misal, belum detailnya data terkait wakaf secara umum demikian juga terkait wakaf tunai.

2. Setelah Indonesia merdeka, regulasi wakaf semakin berkembang positif, dengan keluarnya Peraturan Departemen Agama pada 22 Desember 1953 tentang prosedur pemberian tanah wakaf, yang kemudian diatur kembali oleh Surat Edaran Departemen Agama No. 5/D/1956. Kemudian, diterbitkannya Undang-undang Nomor 5 Tahun 1960 tentang Peraturan Dasar Pokok-Pokok Agraria.

\section{B. SARAN}

Saran yang bisa penulis berikan : Perlu adanya metode penilitian lebih lanjut akan upaya peningkatan dikusi terhadap materi sektor ekonomi ini sebagai salah satu cara memaksimalakan potensi pengetahuan yang baik agar dapat berkembang 


\section{DAFTAR PUSTAKA}

Ali, Marpuji, 'Wakaf Dan Pemberdayaan Umat', Makalah Yang Disampaikan Dalam Seminar on Islamic Economics as a Solution, 2015

Istiana, Tina, 'PERBANDINGAN REGULASI TANAH WAKAF ANTARA INDONESIA DAN MALAYSIA', 2021, 1-17

Kasdi, Abdurrahman, 'Peran Pemerintah Dalam Regulasi Perundang-Undangan Wakaf', ZISWAF : Jurnal Zakat Dan Wakaf, 4(1), 87. Https://Doi.Org/10.21043/Ziswaf.V4i1.3033, $2.2(2015), 362-79$

Nawawi, M. Anwar, 'Pengembangan Wakaf Uang Tunai Sebagai Sistem Pemeberdayaan Umat Dalam Pandangan Ulama Konvensional Dan Kontemporer M.', Journal of Chemical Information and Modeling, 53.9 (2013), 1689-99

Supriyadi, Supriyadi, and Sholihul Hadi, 'Regulasi Wakaf Di Indonesia Dari Masa Orde Lama Sampai Era Reformasi Dalam Tinjauan Politik Hukum', ZISWAF : Jurnal Zakat Dan Wakaf, 6.2 (2019), $204<$ https://doi.org/10.21043/ziswaf.v6i2.6418> Veithzal Rizal ainal, 'PENGELOLAAN DAN PENGEMBANGAN WAKAF PRODUKTIF Oleh : Veithzal Rivai Zainal Anggota Dewan Pertimbangan Badan Wakaf Indonesia (BWI)', Ziswaf, 9 (2016), 1-16 
